\title{
Does Ethnicity Impact Outcome Following Cardiac Surgery?
}

\author{
Pankaj Kumar Mishra ${ }^{1 *}$, Andrew Panayiotou², Alan Nevill ${ }^{3}$, Matthew Thomas ${ }^{1}$, Heyman Luckraz ${ }^{1}$ \\ From World Society of Cardiothoracic Surgeons 25th Anniversary Congress, Edinburgh \\ Edinburgh, UK. 19-22 September 2015
}

\section{Background/Introduction}

Impact of ethnicity on outcome following cardiac surgery is controversial. Current risk stratification models do not include ethnicity as risk factor.

\section{Aims/Objectives}

To assess impact of ethnicity (South-East Asian versus Caucasian) on outcome following cardiac surgery

\section{Method}

Patients of Asian ethnicity who underwent cardiac surgery at our unit between Sep 2005 to Dec 2013 were included in the study $(\mathrm{n}=855)$. This group was matched $1: 2$ with Caucasian patients $(\mathrm{n}=1710)$.

\section{Results}

Pre-operative characteristics confirmed that patients of Asian ethnicity were more likely to be younger [Mean Age $61.7(\mathrm{SD} 11.3) \mathrm{v} / \mathrm{s} 63.2(\mathrm{SD} 10.4)$ years, $\mathrm{p}=0.006$ ], females $(23 \% \mathrm{v} / \mathrm{s} 19 \%, \mathrm{p}=0.03)$ with lower BMI (27 vs 29 , $\mathrm{p}<0.01)$ as compared to Caucasian population. Asian ethnicity was strongly associated with higher prevalence of diabetes $(51 \% \mathrm{v} / \mathrm{s} 22 \%, \mathrm{p}=0.01)$, non-smokers $(69 \% \mathrm{v} / \mathrm{s}$ $30 \%, \mathrm{p}=<0.01)$ and need for urgent surgery ( $42 \% \mathrm{v} / \mathrm{s} 29 \%$, $\mathrm{p}<0.01)$. Post operatively patients with Asian Ethnicity had a higher re-exploration rate $(7.4 \% \mathrm{v} / \mathrm{s} 5.4 \%, \mathrm{p}<0.04)$, higher rate of readmission to ITU $(2.9 \% \mathrm{v} / \mathrm{s} 2.6 \%$, $\mathrm{p}=0.04$ ), a greater need for blood and blood products transfusion requirement (Blood Units $1.23 \mathrm{v} / \mathrm{s} 0.76$, $\mathrm{p}<0.01)$ and was also associated with a higher in-hospital mortality $(2.8 \% \mathrm{v} / \mathrm{s} 1.5 \%, \mathrm{p}=0.02)$. Caucasians had a significantly higher prevalence of post op AF $(26 \% \mathrm{v} / \mathrm{s}$ $17 \%, \mathrm{p}<0.01)$ but shorter ITU (median $1.0(0,90)$ days $\mathrm{v} / \mathrm{s}$.

'Department of Cardiothoracic Surgery, Heart and Lung Centre,

Wolverhampton, UK

Full list of author information is available at the end of the article
$1.5(0,183)$ days, $\mathrm{p}<0.01)$ and in-hospital stay (median 5 $(1,184)$ days v/s. $6(3,183), \mathrm{p}<0.01)$.

\section{Discussion/Conclusion}

Asian ethnicity has an adverse impact on outcome following cardiac surgery, in a matched population. If confirmed in large randomised studies, ethnicity should be made part of future risk stratification models.

\section{Authors' details}

${ }^{1}$ Department of Cardiothoracic Surgery, Heart and Lung Centre Wolverhampton, UK. ${ }^{2} \mathrm{New}$ Cross Hospital, Wolverhampton, UK. ${ }^{3}$ Research Institute of Healthcare Sciences, University of Wolverhampton,

Wolverhampton, UK

Published: 16 December 2015

\section{doi:10.1186/1749-8090-10-S1-A157}

Cite this article as: Mishra et al:: Does Ethnicity Impact Outcome Following Cardiac Surgery? Journal of Cardiothoracic Surgery 2015 10(Suppl 1):A157
Submit your next manuscript to BioMed Central and take full advantage of:

- Convenient online submission

- Thorough peer review

- No space constraints or color figure charges

- Immediate publication on acceptance

- Inclusion in PubMed, CAS, Scopus and Google Scholar

- Research which is freely available for redistribution

Submit your manuscript at www.biomedcentral.com/submit
() Biomed Central 